\title{
Advances of Submarine Groundwater Discharge Studies in South America
}

\author{
Mariele Paiva and Felipe H. Niencheski* \\ Instituto de Oceanografia, Universidade Federal do Rio Grande (FURG), \\ 96201-900 Rio Grande-RS, Brazil
}

\begin{abstract}
Submarine groundwater discharge (SGD) is the hidden portion of water that discharges into the ocean across the ocean-land interface, and it is considered one of the hydrological cycle's major components. Two decades ago, SGD in South America was undocumented, and significant advances on this field has occurred since then. This paper presents the results of SGD investigations, a compilation of the SGD estimations, and the areas lacking of data in South America. The compilation of observed SGD in South America shows that groundwater seepage from the land to the ocean occurs in many environments along the coast. Considering only the few regions for which the total SGD flux was estimated, the SGD flux (ca. $1.2 \times 10^{8} \mathrm{~m}^{3}$ day $\left.^{-1}\right)$ is equivalent in volume to almost $70 \%$ of Amazon River discharge. Although the study of SGD in South America has greatly advanced, many uninvestigated sites and key questions remain.
\end{abstract}

Keywords: land-ocean exchange, subterranean estuary, review, SGD

\section{Introduction}

While rivers are the most obvious lateral pathway of water and material from land to the ocean, a significant proportion of water transverses the terrestrial boundary unseen below the sea surface. ${ }^{1}$ As water flows through the seabed, it facilitates chemical transformations and transports dissolved chemical products to the ocean. The solutes delivered by submarine groundwater discharge (SGD) can be released to the atmosphere, taken up by biota, eventually deposited on the ocean floor or remain in solution (Figure 1). Thus, as fluvial discharge, SGD influences global biogeochemical cycles by delivering solutes from the continents to the oceans. ${ }^{2}$

The contribution of SGD to the chemical budgets of coastal waters was overlooked for many years. Yet, it is nowadays recognized as a major component of the hydrological cycle. ${ }^{3}$ For example, the total flux of SGD to the Atlantic Ocean was found similar in volume to the riverine flux, ${ }^{4}$ and SGD is often composed of water enriched in nutrients, metals, carbon, and bacteria. Therefore, the high SGD fluxes suggest that this process is probably more important than rivers in the oceanic budgets of these materials. ${ }^{3}$

SGD has been reviewed previously by many authors. ${ }^{3,5}$ Over the past two decades, many reviews and national-

*e-mail: niencheski@gmail.com

This paper is part of the PubliSBQ Special Issue "IUPAC-2017" (http://publi.sbq.org.br/).

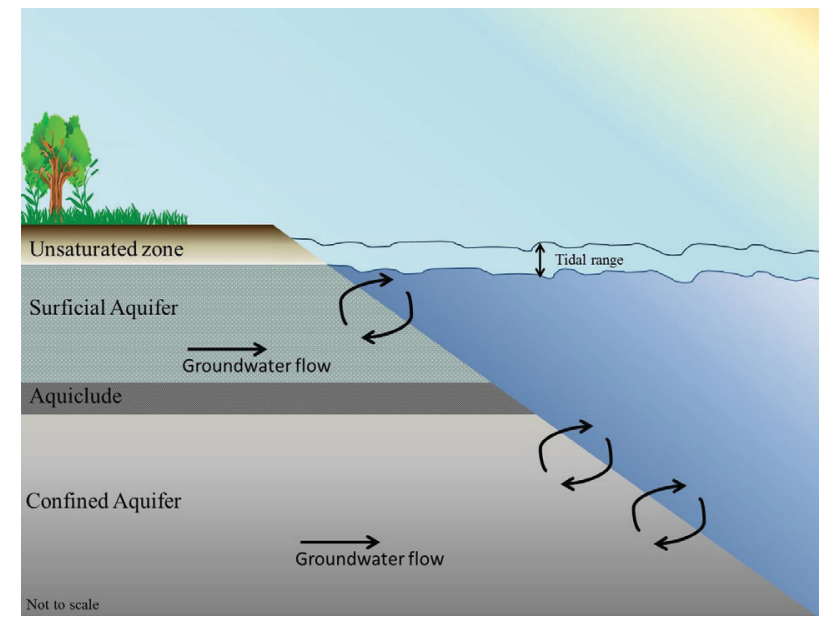

Figure 1. Schematic representation of submarine groundwater discharge (SGD).

scale studies on SGD have also emerged for many specific areas, such as the Baltic Sea, ${ }^{6}$ tropical islands ${ }^{1}$ and part of North America. ${ }^{2,7}$ However, no overview has been undertaken for the studies carried out in South America, a region of the world where many different hydrogeological provinces can be found (e.g., Amazon Sedimentary Basin, Orinoco lowlands, Paraná Sedimentary Basin), ${ }^{8}$ and where significant advances on SGD investigation have occurred in the past two decades. This led us to ask: how much do we know about SGD in South America?

In this review, we have tried to include as many studies as possible to all the SGD related studies undertaken in studying 
this phenomenon, although no review can be completely exhaustive. The objectives of this paper are to present the results of SGD investigations, and to compile the calculated SGD estimations in South America. Furthermore, we shall point out which areas require further analysis and study.

\section{What is SGD?}

Burnett et al. ${ }^{9}$ and Moore ${ }^{3}$ defined SGD as "any and all flow of water on continental margins through the seabed to the coastal ocean, with scale lengths of meters to kilometers, regardless of fluid composition, origin or driving force". SGD does not include such processes as deep-sea hydrothermal circulation, deep fluid expulsion at convergent margins, shear flow, flow driven by benthic fauna, and density-driven cold seeps on continental slopes. ${ }^{3,10,11}$ In other words, SGD is the portion of water (fresh, recirculated seawater and/or salt water) discharged into the ocean across the ocean-land interface, analogously to an estuary discharge, but hidden in the subsurface.

In the subsurface, coastal aquifers consist of a layer (or layers) of water-bearing permeable rock, rock fractures or unconsolidated materials, through which water can easily move. Aquifers do not just stop at the shoreline; they extend beneath the sea floor. Thus, there is a dynamic relationship between the land-derived fresh water (and/or salt water), and seawater that enters the aquifer beyond the coast, recirculates within the aquifer and eventually discharges back into the ocean.

Fresh SGD, terrestrial groundwater discharging into the sea, is controlled by hydraulic gradient between the water table and the sea level, and aquifer characteristics. The aquifer permeability and the hydraulic gradient are the main controlling factors for the amount of water that can be transported through the aquifer. ${ }^{1}$ Additionally, continental groundwater recharge, tidal cycles, winds, wave pumping, density gradients, bioturbation, storms, current-induced pressure gradients, and geothermal heating impact seawater recirculation and freshwater flow. ${ }^{6}$

Independently of its driving force or origin, SGD plays an important role on the biogeochemistry of the ocean. SGD fluxes are linked with nutrients, trace metals, dissolved carbon species fluxes to the ocean. Thus, as SGD can have a significant impact on many processes taking place in the coastal areas, there is a need for the better understanding of this process. ${ }^{3,6}$

\section{Historical Perspective}

The interaction between groundwater and surface water has been studied by hydrogeologists since the XIX century.
The processes that define the relationships between surface and subsurface waters have been target of interest mainly for inland water-resources management. ${ }^{12}$ At the shoreline, the interest was directed landward and attention has been focused only on the identification of the salt water/fresh water "interface" in coastal aquifers, towards to maintaining potable groundwater reserves. ${ }^{9}$

On the other hand, knowledge concerning the undersea discharge of groundwater has existed for many centuries. For example, a source of fresh groundwater four kilometers from the coast of Latakia (Syria) in the Mediterranean Sea was mentioned by Strabo, a Greek geographer who lived in Asia Minor during the transition of the Roman Republic into the Roman Empire. There are many other historical registers. However, the information was not driven by scientific curiosity. ${ }^{13}$

Up to the 1990, the literature on submarine groundwater discharge (SGD) was scattered and fragmentary., ${ }^{3,14}$ This was related to two factors: (i) the difficulty in finding and measuring these features, ${ }^{13}$ and (ii) the assumption that SGD was a rare and negligible phenomenon. ${ }^{14}$

SGD occurs wherever an aquifer (i.e., a body of saturated permeable rock, rock fractures or unconsolidated materials through which water can easily move) is connected hydraulically with the sea through permeable bottom sediments, and the head is above sea level. ${ }^{9,14}$ Thus, SGD cannot be a process restricted to few areas.

Indeed, ten years after Johanes ${ }^{14}$ pointed out SGD as a biogeochemical important process for the coastal ocean, a set of papers was published in this field ${ }^{15}$ reporting measurements of SGD, and its biogeochemical impacts, in different localities.

In 1996, Moore ${ }^{16}$ discovered high activities of ${ }^{226} \mathrm{Ra}$ in the South Atlantic Bight (United States coast) that could not be explained by input from rivers or sediments, which led to the hypothesis that SGD was responsible for the elevated activities in the coastal ocean. ${ }^{16}$ Since then, the Scientific Committee on Ocean Research (SCOR) working group on submarine groundwater discharge was formed, ${ }^{17}$ and the study of SGD and related phenomena expanded rapidly all over the world.

In South America, the studies directly related to SGD were initiated in the north coast of Bahia, ${ }^{18}$ followed by investigations in a series of small embayments of the northernmost part of São Paulo Bight, southeastern Brazil, ${ }^{19}$ as well as at the barrier spit adjacent to the Patos Lagoon on the southern coast of Brazil. ${ }^{20}$ This inprogress research has extended our knowledge of SGD to areas where the role of SGD was unknown, yet further investigation in many key areas remains, as it is shown is this review. 


\section{SGD Assessment}

Detection and estimation of SGD have been carried out through many approaches, from direct terrestrial water budgets to infrared imaging. There is a detailed review article on methods to measure SGD. ${ }^{21}$ Thus, we shall mention it in general terms.

There are four principles that regulate the approaches used in SGD assessment: (i) modeling; (ii) direct physical measurement; (iii) chemical tracers; and (iv) geophysical tracers.

Several modeling approaches have been applied for SGD estimation, ranging in complexity from simple onshore groundwater mass balance calculations through to comparatively complex numerical models of sub-surface flow. While numerical models have provided insights and increased our predictive capabilities, a lack of sediment permeability data, experimental and in situ measurements, remain a problem for the application and validation of the models. ${ }^{21,22}$

Direct physical measurements have been conducted since the very beginning of SGD investigation, ${ }^{23}$ commonly through measurement of the direction and magnitude of hydraulic gradients across the sediment-water interface or through "seepage meters". This device was originally developed to measure the water loss from irrigation canals. It consists of benthic chambers attached to a plastic bag partially filled with a known volume of seawater. The volume changes in the bag represent the flux of water out of or into the sediment. ${ }^{21}$ Several automated variations have been developed, based on temperature, ${ }^{24}$ absorbance, ${ }^{25}$ and ultrasoni ${ }^{26}$ measurements. The main problem with seepage meters is that: the flow can be extremely variable in both time and space; as the seepage meter cover only a small area, many measurements might be needed to get reliable averages. ${ }^{13,21,22}$

Chemical tracers (natural and artificial tracers) have been applied to evaluate groundwater discharge rates into the ocean in many ways. The most popular is the use of enriched geochemical tracers in the groundwater relative to the seawater. ${ }^{22}$ Briefly, in these techniques the concentration of a solute in excess (i.e., unrelated to other known sources) in the receiving water body is attributed to inputs from groundwater. ${ }^{16,27}$ The groundwater tracers have the advantage of presenting an integrated signal as they enter the marine water column via various pathways in the aquifer. Therefore, small temporal and spatial variabilities tend to be smoothed out over time and space..$^{28}$ On the other hand, natural tracers require that all other tracer sources and sinks except groundwater be evaluated, which is often challenging. ${ }^{13}$
Geophysical tracers such as conductivity and temperature can also be used to estimate groundwater discharge rates. The electrical bulk ground conductivity (or its inverse, resistivity) is a measure of how much salt is present in marine sediments, which is a function of sediment porosity, pore water salinity and temperature. Permeable sediments containing seawater have high conductivity, which decreases with salinity. Thus, bulk ground conductivity profiles are very useful in mapping subsurface zones of brackish or freshwater, and can be employed to investigate the flow paths of fresh, terrestriallyderived groundwater. ${ }^{3,29}$ Temperature is applied as a tracer considering: $(i)$ temperature-depth profiles (under the assumption of conservative heat conduction-advection transport); and (ii) the differences of temperature in the groundwater-surface water system as a qualitative signal of groundwater seepage, using techniques such as infrared sensors or other remote sensing methods. ${ }^{21}$

\section{South America SGD Investigation}

Taking into account the length of the South American coastline (about 30,000 km), specific SGD rate estimates have been performed on a few areas (Table 1). In order to compile existing SGD data in South America, we present all available studies that estimated or indicated the occurrence of SGD in the studied area (Figure 2). In this study, we considered indistinctly all fresh, recirculated seawater and salt water components of SGD (see section 2).

As all over the world, the earlier studies of seawatergroundwater exchange in South America were largely motivated by groundwater resources issues. ${ }^{59}$ Aiming to identify and estimate fresh water reservoirs for societal use, the very first studies were conducted in the light of hydrogeological and water balance models.

Estimative based on hydrogeological model has been conducted for the entire South America coast by Zektser et al. ${ }^{60}$ These authors estimated fluxes of fresh groundwater into the ocean using an integrated hydrologichydrogeological approach. This approach assumes that specific hydrogeological provinces have the groundwater input to rivers similar to groundwater discharge to the ocean. Based on published data, the groundwater input to the rivers was estimated, and the expected discharge per kilometer of river with the shoreline length of each province was scaled. Then, the groundwater fluxes from each province to the ocean were provided. According to the authors, this approach may miss fluxes from zones deeper than the upper zones draining into rivers. ${ }^{3}$

Considering the heterogeneity of SGD, models are useful for investigating SGD, but they probably are not 
Table 1. Regional submarine groundwater discharge (SGD) investigations

\begin{tabular}{|c|c|c|c|c|}
\hline Region & Country & SGD rate $/\left(\mathrm{cm} \mathrm{day}^{-1}\right)$ & SGD flux $/\left(\mathrm{m}^{3}\right.$ day $\left.^{-1}\right)$ & Reference \\
\hline Arraial do Cabo (RJ) ${ }^{\mathrm{a}}$ & Brazil & 6.0 & $2.6 \times 10^{3}$ & 30 \\
\hline Callao & Peru & & & 31 \\
\hline Chanaral & Chile & & & 32 \\
\hline Chubut & Argentina & & & d \\
\hline Córdoba & Argentina & & & 33 \\
\hline Hornitos & Chile & & & 34 \\
\hline Ite Bay & Peru & & & 32,35 \\
\hline Lima & Peru & & $2.3 \times 10^{5}-3.5 \times 10^{5}$ & 31 \\
\hline Mar Chiquita & Argentina & & & 36 \\
\hline Mid Bahia & Brazil & 142 & $2.6 \times 10^{7}$ & 37 \\
\hline North Bahia & Brazil & 4.5 & & 18 \\
\hline North $\mathrm{RS}^{\mathrm{b}}$ & Brazil & 3.5 & $8.5 \times 10^{7}$ & $20,38-42$ \\
\hline NE Sao Paulo & Brazil & $0-360$ & & $19,21,43-47$ \\
\hline Paranagua $(\mathrm{PR})^{\mathrm{c}}$ & Brazil & & & 48 \\
\hline Pernambuco & Brazil & & & d \\
\hline Pontal do Parana $(\mathrm{PR})^{\mathrm{c}}$ & Brazil & & $1.6 \times 10^{4}$ & 49 \\
\hline Sepetiba Bay $(\mathrm{RJ})^{\mathrm{a}}$ & Brazil & 5.0 & $1 \times 10^{7}-3.75 \times 10^{7}$ & 50,51 \\
\hline South Bahia & Brazil & $2.1-2.7$ & & 52 \\
\hline South RS ${ }^{\mathrm{b}}$ & Brazil & & & $53-55$ \\
\hline Suriname & Suriname & & & 56,57 \\
\hline Surquillo & Peru & & & 11 \\
\hline
\end{tabular}

aRio de Janeiro, ${ }^{\text {} R i o ~ G r a n d e ~ d o ~ S u l, ~}{ }^{\text {PParaná; }}{ }^{\mathrm{d} N i e n c h e s k i, ~ L . ~ F ., ~ u n p u b l i s h e d ~ d a t a . ~}$

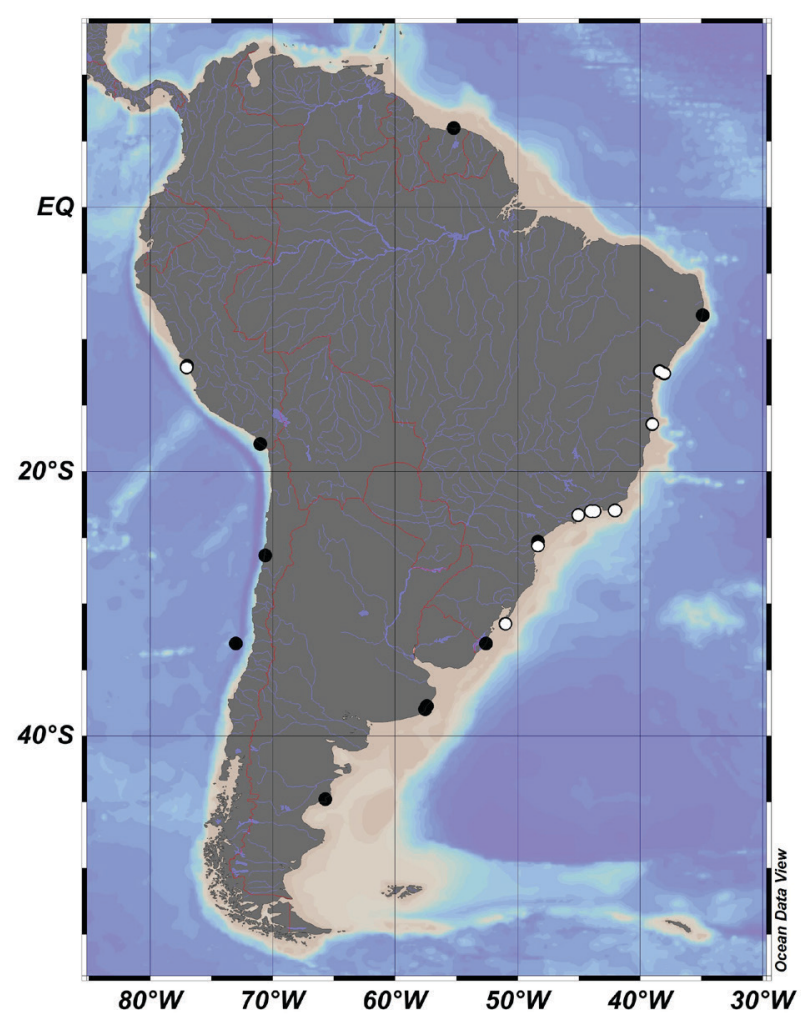

Figure 2. Location of submarine groundwater discharge (SGD) investigations in South America (Ocean Data View software, freely available). ${ }^{58}$ The white dots indicate the sites where quantitative estimations have been conducted. yet a substitute for direct measurements. ${ }^{13}$ Therefore, the variety of aspects related to SGD can be better addressed by investigations using a combination of approaches, i.e., modeling, direct physical measurement; chemical and geophysical tracers. ${ }^{3}$

\subsection{SGD studies in the Peruvian Coast}

In the coastal region of Lima (Peru), the hydrogeological map given in Karakouzian et al. ${ }^{61}$ shows the flow of groundwater to the ocean. The SGD rate was estimated, through water balances, between 2.7 and $4.1 \mathrm{~m}^{3} \mathrm{~s}^{-1} .{ }^{31}$ Indeed, during the cruise SO 147 of the German research vessel SONNE in July 2000, a large decrease in pore water salinity with depth was found at a shallow-water location in the Pisco Basin. However, a study based on stable isotopes data $\left(\delta^{2} \mathrm{H}\right.$ and $\left.\delta^{18} \mathrm{O}\right)$ and modeling revealed that the observed pore water freshening can be conclusively explained by diffusive mixing of seawater with meteoric water, which infiltrated during the last sea level low stand and stayed entrapped during transgression and sedimentation. ${ }^{31}$

In 2007, Dold ${ }^{32}$ addressed the remediation strategy of a costal tailing deposit in Bahia de Ite (Peru). Through geochemical modeling and isotopic signatures, these authors described the element cycling in the subterranean estuary of this man-impacted area. Additionally, they 
mentioned that alkaline fresh groundwater from the high Andes flows through the coastal aquifer and tailings deposit toward the sea, which was further discussed by Dold et al. ${ }^{35}$ Recently, Moosdorf and Oehler ${ }^{11}$ mentioned that fresh SGD is pumped right at the beach and distributed by trucks near Lima (Surquillo, Peru). However, a quantitative approach has not been reported.

\subsection{SGD in the coast of Suriname}

A large amount of relatively fresh groundwater was found further offshore of Suriname coast. ${ }^{59}$ Yet, further studies conducted in Suriname concluded that there is no active groundwater flow system, with onshore recharge and submarine discharge..$^{56,57}$ The fresh groundwater reservoir is, instead, paleo groundwater, formed during the Wisconsin sea level when recharge was higher and occurred in the entire coastal plain. ${ }^{56}$

\subsection{SGD in the coast of Brazil}

\subsubsection{SGD investigation in the Northeast}

The potential biogeochemical impact of SGD-related input was first addressed in the north coast of Bahia. ${ }^{18}$ This study indicated that differences between lake and sea level can reach $5.9 \mathrm{~m}$ at low tides, generating an SGD advective rate from 2.0 up to $4.5 \mathrm{~cm}$ day $^{-1}$ toward the coastal reefs (Table 1). The authors also showed the impact of population growth on the groundwater quality, and the eutrophication of coral reefs due to the high nutrient load through SGD.

Studies in Bahia State were expanded to its southern region, where coral reef demise has been related to the high SGD-input of nutrient. ${ }^{52}$ During the rainy season, a marked increase in nutrient concentrations was found near the bottom between Coroa Vermelha reef, and Recife de Fora. ${ }^{62,63}$ The advective rates toward the coral reefs were estimated between 2.1 and $2.7 \mathrm{~cm}$ day $^{-1} .{ }^{62}$

Recently, SGD was addressed at the Todos os Santos Bay, in the mid coast of Bahia State. ${ }^{37}$ Using short-lived radium isotopes, an advective rate of $142 \mathrm{~cm} \mathrm{day}^{-1}$ was estimated. Considering the entire bay, it was found a total groundwater flux up to $300 \mathrm{~m}^{3} \mathrm{~s}^{-1}$, which represents three times the average river discharge into the bay.

Preliminary data from the coastal water of Pernambuco, characterized by the presence of coral reefs, showed activities of ${ }^{222} \mathrm{Rn}$ (from $1.72 \pm 1.0$ to $2.23 \pm 1.48 \mathrm{dpm}$ per $100 \mathrm{~L}$ ) slightly higher than the activities found in riverine waters of the region, from $0.95 \pm 0.51$ to $1.36 \pm 0.68 \mathrm{dpm}$ per $100 \mathrm{~L}$ (Niencheski, unpublished data). Although further investigations are needed, this might indicate SGD toward the coral reefs, as it has been shown for the coast of Bahia.

\subsubsection{SGD investigations in the Southeast}

In a set of embayments from the Northeast coast of São Paulo, Oliveira et al. ${ }^{19}$ found a very dynamic and tidally influenced SGD. These authors reported an advective rate between 1.4 to $23.0 \mathrm{~cm} \mathrm{day}^{-1}$, considering both applied methods ( ${ }^{222} \mathrm{Rn}$ and seepage meter). Later on, in advance of a joint project of UNESCO and the International Atomic Energy Agency (IAEA), this region was one of the five investigated sites around the world. ${ }^{21}$ Characterized by the presence of fractured crystalline rocks, this site was extensively studied with respect to SGD, by means of seepage meters, ${ }^{45}$ electric resistivity of the seabed and of the electric conductivity of SGD, ${ }^{29,64}$ radium isotopes, ${ }^{43}{ }^{222} \mathrm{Rn},{ }^{44}$ and artificial tracers. ${ }^{46}$ In addition, the hydrogeology and geochemistry of the SGD in this region was investigated by Oberdorfer et al..$^{47}$

Briefly, the main conclusions from the research carried out in the Northeast coast of São Paulo were: (i) the estimated advection rates across the seabed ranged from 0 to $360 \mathrm{~cm} \mathrm{day}^{-1}$, and it is greatly variable in both time and space; (ii) temporal variation in groundwater flow is mainly controlled by precipitation, since recharge was governed largely by this phenomenon (lag-time of discharge after recharge is in the order of one to a few days); (iii) SGD is also modulated by the tides, with the highest values occurring at times of low tide, but the interaction is non-linear; (iv) the irregular spatial distribution is related to the fractured rock aquifer, which is a primary SGD driver in this region; $(v)$ the freshwater within the aquifer has a short residence time, insufficient for significant alteration of water chemistry through weathering of feldspar minerals; (vi) the maximum terrestrially derived SGD was found $50 \mathrm{~m}$ offshore, but the highest total SGD was found closer to the shore, with a lower fresh groundwater component; (vii) SGD appears to be a net source of nutrients to the overlying water column, though other land-derived pathways may be as important or greater than SGD.

In Sepetiba Bay (Rio de Janeiro State), Sanders et al..$^{50}$ illustrated the importance of the mangrove subterranean estuary as a biogeochemical reactor, which acts as a source of metals to the seawater through SGD. Smoak et al..$^{51}$ applied a radium mass balance to the same region to estimate the volume of SGD into the bay. These authors found SGD fluxes varying between $1 \times 10^{10}$ to $3.75 \times 10^{10} \mathrm{~L} \mathrm{day}^{-1}$, and suggested that a substantial portion of the SGD in Sepetiba Bay consists of infiltrated seawater. The normalized SGD rate reported is approximately $5.0 \mathrm{~cm}$ day $^{-1}$.

In 2013, Godoy et al..$^{30}$ conducted a research in Arraial do Cabo (Rio de Janeiro State), $200 \mathrm{~km}$ west from Sepetiba Bay. These authors found, through multiple tracers of SGD, an advective rate of $6.0 \mathrm{~cm} \mathrm{day}^{-1}$, constituted of recirculated 
seawater, due to the existence of a physical barrier which hinders the existence of freshwater SGD and also the groundwater pumping close to the shoreline.

\subsubsection{SGD investigations in the South}

The pioneer SGD-study in the south of Brazil investigated interstitial waters samples, and found SGD through the permeable barrier between Patos Lagoon and the ocean. ${ }^{20}$ This study has been expanded since then.

In 2006, Windom et al..$^{38}$ reported a study of coastal waters using radium isotopes to quantify SGD advecting through coastal permeable sands into the Atlantic. Using the advective rate $\left(3.5 \mathrm{~cm} \mathrm{day}^{-1}\right)$ and dissolved $\mathrm{Fe}$ measurements in the coastal waters, these authors calculated that the cross-shelf Fe flux from this $240 \mathrm{~km}$ coastline is equivalent to about $10 \%$ of the atmospheric flux to the entire South Atlantic Ocean. Another study, based on numerical modeling, demonstrated that geochemical tracer techniques (such as radium quartet) characterize only the component of benthic discharge flux that transports the tracer. ${ }^{42}$ Thus, depending on either constructive or destructive interaction of the benthic flux components, the SGD flux to this area can be even greater.

Well along, Niencheski et al. ${ }^{39}$ estimated the SGD-related nutrient input to the same region. These authors found that SGD may represent as much as $55 \%$ of the total nitrogen flux to the adjacent shelf environment. Also reported by Moore ${ }^{65}$ the results suggest that the chemistry of the shelf waters of this region is substantially affected by SGD.

Indeed, studying the hydrochemistry of the distribution of dissolved ${ }^{228} \mathrm{Ra}$, and trace elements on the entire shelf (adjacent to Rio Grande do Sul State), Niencheski et al..$^{40}$ concluded that the SGD is the main source of dissolved Co, $\mathrm{Mn}$ and $\mathrm{Fe}$ to this region. From a dataset of groundwater and surface water analysis, Niencheski and Windom ${ }^{41}$ demonstrated that the Patos Lagoon Barrier Aquifer acts as a reactive reservoir that alters the land-sea flux. For example, it enhances the flux of $\mathrm{Fe}$ and $\mathrm{Mn}$ and diminishes the flux of $\mathrm{Cu}$, significantly influencing adjacent coastal water chemistry.

Further south in Rio Grande do Sul State $\left(52.6^{\circ} \mathrm{W}\right.$, $33.0^{\circ} \mathrm{S}$ ), a study based on silicate, nitrogen and phosphate data from three offshore transects ${ }^{53}$ suggested a significant SGD-related nutrient input from Mangueira Lagoon to the coastal ocean. In 2011, Schmidt et al. ${ }^{55}$ demonstrated, through stable isotopes signatures $\left(\delta^{18} \mathrm{O}, \delta^{2} \mathrm{H}\right)$ of different endmembers, that the water from Mangueira Lagoon does not discharge through the barrier system into the sea. These authors suggested instead that the rainwater infiltrating the aquifer is the main source of groundwater discharging into the ocean. Later, Attisano et al. ${ }^{54}$ suggested a paleo-drainage feature, located $80 \mathrm{~km}$ from the coastline of this region, as a preferential route for the exchange between the seawater and submarine groundwater.

In Paraná State, a model-based study was conducted in Pontal do Paraná. ${ }^{49}$ These authors found an SGD discharge of ca. 16,000 $\mathrm{m}^{3}$ day $^{-1}$ across the interface between the freshwater aquifer zone and the sea. In the same state, Dias $e$ e al $^{48}$ suggested that the large variations of radium activity in Paranaguá Bay are likely due to the inputs from SGD. However, no quantitative estimation was provided.

\subsection{SGD in the coast of Chile}

In 2007, a study related to marine shore tailing deposits and their remediation described the discharge of highly saline groundwater from the Salar de Pedernales (salinity up to 56) into the Bay of Chanaral, Atacama Region. ${ }^{32}$ According to these authors, the coastal water of this region is affected by $\mathrm{As}, \mathrm{Mo}, \mathrm{Cu}$ and $\mathrm{Zn}$ inputs through this pathway.

In another study of surf clam ecology, Riascos et al..$^{34}$ observed low salinity submarine seepage (average $=19.5$; standard deviation $(\mathrm{SD})=11.3 ; \mathrm{n}=12$ ) in the shallow subtidal zone of Hornitos, northern Chile. According to the authors, the features of low salinity groundwater flow at Hornitos most likely correspond to SGD. However, no quantitative estimation was provided.

\subsection{SGD in the coast of Argentina}

Fanjul et al., ${ }^{36}$ studying intertidal areas of SW Atlantic coast of Argentina, reported changes in permeability of the sediment due to the burrows and galleries constructed by Neohelice granulata. These authors concluded that bioturbating organisms may affect quantitative and qualitative the export of nutrients from salt marshes to the open estuarine/coastal waters, through SGD. In 2014, Marchetti and Carrillo-Rivera ${ }^{33}$ investigated the groundwater flow to a floodplain in Argentina, and suggested that groundwater occurs in the sea, based on the topographic altitude.

Currently, a joint program of MINCyT (Argentina) and CAPES (Brazil) is taking place in the mid-east Atlantic coast of Argentina. The main goal of the research is to understand the role of SGD inputs on the marine biogeochemistry of the region. Preliminary data of ${ }^{222} \mathrm{Rn}$ and radium isotopes suggest that SGD can be an important process in particular areas of Patagonia's coastal region. In this region, the hydraulic gradient is likely the main driving force that results in fresh submarine groundwater discharge (Niencheski, L. F., unpublished data). 


\section{Final Remarks}

The compilation of South America SGD studies shows that, from the 21 investigated sites, a quantitative approach (either the rate or the total flux) has been conducted to only nine of them. Considering only the six regions for which the total SGD flux $\left(\mathrm{m}^{3}\right.$ day $\left.^{-1}\right)$ has been estimated (Arraial do Cabo, Lima, Todos os Santos Bay, North of Rio Grande do Sul State, Pontal do Paraná, and Sepetiba Bay), it can be concluded that the SGD total flux (ca. $1.2 \times 10^{8} \mathrm{~m}^{3}$ day $^{-1}$ ) is equivalent in volume to almost $70 \%$ of Amazon River discharge. Thus, a continent-wide estimative of SGD must be much greater. Indeed, a ${ }^{228} \mathrm{Ra}$-based ${ }^{4}$ study emphasized that "the ${ }^{228} \mathrm{Ra}$ inventory near the Amazon River mouth is not significantly greater than in boxes intersecting other parts of the South American continent, which supports the conclusion that SGD dominates riverine and sedimentary input of ${ }^{228} \mathrm{Ra}{ }^{66}$.

We were unable to find any indications of groundwater discharge reported for Guyana, French Guiana, Venezuela, Colombia, Ecuador, and Uruguay. Data are particularly lacking from Chile, Peru, Argentina, Espírito Santo and Santa Catarina states, and some states of North and Northeast coast of Brazil (Figure 2). This indicates where future effort should be concentrated to advance the current state of the art concerning the distribution and magnitude of SGD in South America.

Although significant advances and insights have occurred in the preceding two decades, key questions remain:

- How significant is SGD for the biologically driven carbon uptake in Southwest Atlantic Ocean, and Southeast Pacific Ocean?

- What is the role of the terrestrial component of groundwater on the transport of pollutants to coastal oceans?

- How significant is SGD as a carbon source to the Southeast Pacific and Southwest Atlantic Coasts?

- Which coastal aquifers of the South America coast are susceptible to salinization?

- What is the role of SGD input beyond the coastal ocean?

- Which changes in temporal and spatial variability of SGD can we expect in response to climate changes?

Efforts approaching representative types of coastal aquifers, climate conditions and environmental dynamics are necessary to more completely describe SGD on regional and global scales. We believe that international cooperative research programs may promote and improve our understanding of this important exchange process between land and sea in South America, which is recognized as a major component of the hydrological cycle.

\section{Acknowledgments}

The authors would like to thank the referees for their valuable comments which helped to improve the manuscript. Paiva and Niencheski acknowledge, respectively, the grants from Coordination for the Improvement of Higher Education Personnel (CAPES, PDSE, 88881.133237/201601), and CNPq (303672/2013-7).

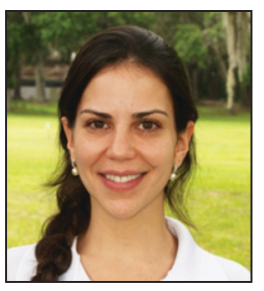

Mariele Paiva holds a Master's in Chemical Oceanography, and currently is a PhD candidate from Universidade Federal do Rio Grande (Brazil). Her main research interest includes the application of radioactive tracers to investigate ocean processes, such as submarine groundwater discharge.

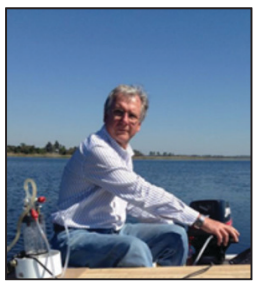

Felipe Niencheski earned a PhD at Université d'Aix-Marseille II in 1982. Currently, he is a Professor at Universidade Federal do Rio Grande (FURG, Brazil), Adjunct Faculty Member of Skidaway Institute of Oceanography (USA), and member of the Scientific Steering Committee of GEOTRACES. He was a member of GIPME (Global Investigation of Pollution in the Marine Environment)/IOC. His research interests are: Estuarine and Marine Chemistry; the study of the modification of nutrients and TEI's (trace elements and their isotopes) during the transition from the fluvial to fully marine conditions; and submarine groundwater discharge (SGD).

\section{References}

1. Moosdorf, N.; Stieglitz, T.; Waska, H.; Dürr, H. H.; Hartmann, J.; Grundwasser 2015, 20, 53.

2. Sawyer, A. H.; David, C. H.; Famiglietti, J. S.; Science 2016, 3, 706 .

3. Moore, W. S.; Annu. Rev. Mar. Sci. 2010, 2, 59.

4. Moore, W. S.; Sarmiento, J. L.; Key, R. M.; Nat. Geosci. 2008, 1,309 .

5. Taniguchi, M.; Burnett, W. C.; Cable, J. E.; Turner, J. V.; Hydrol. Processes 2002, 16, 2115; Kim, G.; Ryu, J.-W.; Yang, H.-S.; Yun, S.-T.; Earth Planet. Sci. Lett. 2005, 237, 156; Gallardo, A. H.; Marui, A.; Geo-Mar. Lett. 2006, 26, 102.

6. Szymczycha, B.; Pempkowiak, J. In The Role of Submarine Groundwater Discharge as Material Source to the Baltic Sea; Springer International Publishing: Cham, Switzerland, 2016. 
7. McCoy, C. A.; Corbett, D. R.; J. Environ. Manage. 2009, 90, 644.

8. Rebouças, A. C.; Episodes 1999, 22, 232.

9. Burnett, W.; Bokuniewicz, H.; Huettel, M.; Moore, W.; Taniguchi, M.; Biogeochemistry 2003, 66, 3.

10. Bratton, J. F.; J. Geol. 2010, 118, 565.

11. Moosdorf, N.; Oehler, T.; Earth-Sci. Rev. 2017, 171 (Supplement C), 338.

12. Sophocleous, M.; Hydrogeol. J. 2002, 10, 52.

13. UNESCO; Submarine Groundwater Discharge: Management Implications, Measurements and Effects; UNESCO: Paris, 2004.

14. Johannes, R. E.; Mar. Ecol.: Prog. Ser. 1980, 3, 365.

15. Valiela, I.; D’Elia, C.; Biogeochemistry 1990, 10, 175.

16. Moore, W. S.; Nature 1996, 380, 612.

17. Burnett, B.; Trans., Am. Geophys. Union 1999, 80, 13.

18. Costa, O. S.; Leão, Z. M. A. N.; Nimmo, M.; Attrill, M. J.; Hydrobiologia 2000, 440, 307.

19. Oliveira, J.; Burnett, W. C.; Mazzilli, B. P.; Braga, E. S.; Farias, L. A.; Christoff, J.; Furtado, V. V.; J. Environ. Radioact. 2003, $69,37$.

20. Windom, H.; Niencheski, F.; Mar. Chem. 2003, 83, 121.

21. Burnett, W. C.; Aggarwal, P. K.; Aureli, A.; Bokuniewicz, H.; Cable, J. E.; Charette, M. A.; Kontar, E.; Krupa, S.; Kulkarni, K. M.; Loveless, A.; Moore, W. S.; Oberdorfer, J. A.; Oliveira, J.; Ozyurt, N.; Povinec, P.; Privitera, A. M. G.; Rajar, R.; Ramessur, R. T.; Scholten, J.; Stieglitz, T.; Taniguchi, M.; Turner, J. V.; Sci. Total Environ. 2006, 367, 498.

22. Santos, I. R.; Eyre, B. D.; Huettel, M.; Estuarine, Coastal Shelf Sci. 2012, 98, 1.

23. Vanek, V.; J. Hydrol. 1993, 151, 317; Bugna, G. C.; Chanton, J. P.; Cable, J. E.; Burnett, W. C.; Cable, P. H.; Geochim. Cosmochim. Acta 1996, 60, 4735.

24. Taniguchi, M.; Iwakawa, H.; J. Groundwater Hydrol. 2001, 43, 271.

25. Sholkovitz, E.; Herbold, C.; Charette, M.; Limnol. Oceanogr.: Methods 2003, 1, 16.

26. Paulsen, R. J.; Smith, C. F.; O’Rourke, D.; Wong, T. F.; Groundwater 2001, 39, 904.

27. Cable, J. E.; Bugna, G. C.; Burnett, W. C.; Chanton, J. P.; Limnol. Oceanogr. 1996, 41, 1347.

28. Burnett, W. C.; Taniguchi, M.; Oberdorfer, J.; J. Sea Res. 2001, 46, 109 .

29. Stieglitz, T.; Taniguchi, M.; Neylon, S.; Estuarine, Coastal Shelf Sci. 2008, 76, 493.

30. Godoy, J. M.; Souza, T. A.; Godoy, M. L. D.; Moreira, I.; Carvalho, Z. L.; Lacerda, L. D.; Fernandes, F. C.; Mar. Chem. 2013, 156, 85 .

31. Kriete, C.; Suckow, A.; Harazim, B.; Estuarine, Coastal Shelf Sci. 2004, 59, 499.

32. Dold, B.; Adv. Mater. Res. 2007, 20, 177.

33. Marchetti, Z. Y.; Carrillo-Rivera, J. J.; River Res. Appl. 2014, $30,166$.
34. Riascos, J. M.; Carstensen, D.; Laudien, J.; Arntz, W. E.; Oliva, M. E.; Güntner, A.; Heilmayer, O.; Mar. Ecol.: Prog. Ser. 2009, 385,151 .

35. Dold, B.; Diaby, N.; Spangenberg, J. E.; Environ. Sci. Technol. 2011, 45, 4876.

36. Fanjul, E.; Grela, M. A.; Canepuccia, A.; Iribarne, O.; Estuarine, Coastal Shelf Sci. 2008, 79, 300.

37. Hatje, V.; Attisano, K. K.; de Souza, M. F. L.; Mazzilli, B.; de Oliveira, J.; Mora, T. A.; Burnett, W. C.; J. Environ. Radioact. 2017, 178 (Supplement C), 136.

38. Windom, H. L.; Moore, W. S.; Niencheski, L. F. H.; Jahnke, R. A.; Mar. Chem. 2006, 102, 252.

39. Niencheski, L. F. H.; Windom, H. L.; Moore, W. S.; Jahnke, R. A.; Mar. Chem. 2007, 106, 546.

40. Niencheski, L.; Windom, H.; Moore, W.; Cont. ShelfRes. 2014, $88,126$.

41. Niencheski, L. F. H.; Windom, H. L.; J. Coastal Res. 2014, 31, 1417.

42. King, J. N.; Water Resour. Res. 2012, 48, W12530, DOI 10.1029/2011WR011477.

43. Godoy, J. M.; Carvalho, Z. L.; Fernandes, F. C.; Danelon, O. M.; Godoy, M. L. D.; Ferreira, A. C. M.; Roldão, L. A.; J. Braz. Chem. Soc. 2006, 17, 730; Oliveira, J.; Elísio, A.; Teixeira, W.; Peres, A.; Burnett, W.; Povinec, P.; Somayajulu, B.; Braga, E.; Furtado, V.; J. Coastal Res. 2006, 1084; Moore, W. S.; de Oliveira, J.; Estuarine, Coastal Shelf Sci. 2008, 76,512 .

44. Oliveira, J.; Costa, P.; Braga, E.; J. Radioanal. Nucl. Chem. 2006, 269, 689; Povinec, P.; de Oliveira, J.; Braga, E.; Comanducci, J.-F.; Gastaud, J.; Groening, M.; Levy-Palomo, I.; Morgenstern, U.; Top, Z.; Estuarine, Coastal Shelf Sci. 2008, 76, 522.

45. Bokuniewicz, H.; Taniguchi, M.; Ishitoibi, T.; Charette, M.; Allen, M.; Kontar, E. A.; Estuarine, Coastal Shelf Sci. 2008, 76,466

46. Cable, J. E.; Martin, J. B.; Estuarine, Coastal Shelf Sci. 2008, $76,473$.

47. Oberdorfer, J. A.; Charette, M.; Allen, M.; Martin, J. B.; Cable, J. E.; Estuarine, Coastal Shelf Sci. 2008, 76, 457.

48. Dias, T. H.; de Oliveira, J.; Sanders, C. J.; Carvalho, F.; Sanders, L. M.; Machado, E. C.; Sá, F.; Mar. Pollut. Bull. 2016, 111, 443.

49. Babu, D. S.; Sahai, A. K.; Noernberg, M. A.; Marone, E.; Hydrogeol. J. 2008, 16, 1427.

50. Sanders, C. J.; Santos, I. R.; Barcellos, R.; Silva Filho, E. V.; Cont. Shelf Res. 2012, 43, 86.

51. Smoak, J. M.; Sanders, C. J.; Patchineelam, S. R.; Moore, W. S.; J. South Am. Earth Sci. 2012, 39, 44.

52. Costa, O. S.; Attrill, M. J.; Nimmo, M.; J. Mar. Syst. 2006, 60, 63.

53. Attisano, K. K.; Niencheski, L. F. H.; Milani, I. C. B.; Machado, C. S.; Milani, M. R.; Zarzur, S.; Andrade, C. F. F.; Braz. J. Oceanogr. 2008, 56, 189. 
54. Attisano, K. K.; Santos, I. R.; Andrade, C. F. F.; Paiva, M. L.; Milani, I. C. B.; Niencheski, L. F. H.; Braz. J. Oceanogr. 2013, $61,195$.

55. Schmidt, A.; Santos, I. R.; Burnett, W. C.; Niencheski, F.; Knöller, K.; J. Hydrol. 2011, 406, 66.

56. Groen, J.; Velstra, J.; Meesters, A. G. C. A.; J. Hydrol. 2000, 234,1 .

57. Kooi, H.; Groen, J.; J. Hydrol. 2001, 246, 19.

58. Schlitzer, R.; Ocean Data View, 2017. Available at https://odv. awi.de/, accessed in November 2017.

59. Groen, J. In The History of Earth Sciences in Suriname; Wong, T. E.; De Vletter, D. R.; Krook, L.; Zonneveld, J. I. S.; Van Loon, A. J., eds.; Royal Netherlands Academy of Arts and Sciences, Netherlands Institute of Applied Geoscience: Amsterdam, 1998, p. 129.
60. Zektser, I. S.; Everett, L. G.; Dzhamalov, R. G.; Submarine Groundwater; CRC Press: Boca Raton, USA, 2006.

61. Karakouzian, M.; Candia, M. A.; Wyman, R. V.; Watkins, M. D.; Hudyma, N.; Bull. Assoc. Eng. Geol. 1997, 3, 55.

62. Costa Jr., O. S.; Braz. J. Oceanogr. 2007, 55, 265.

63. Costa, O. S.; Nimmo, M.; Attrill, M. J.; J. South Am. Earth Sci. 2008, 25, 257.

64. Taniguchi, M.; Stieglitz, T.; Ishitobi, T.; Estuarine, Coastal Shelf Sci. 2008, 76, 484.

65. Moore, W. S.; J. Geochem. Explor. 2006, 88, 389.

66. Moore, W. S.; Global Biogeochem. Cycles 2010, 24, GB4005, DOI 10.1029/2009GB003747.

Submitted: October 6, 2017 Published online: December 5, 2017 